\title{
PREDICTORS OF THE SENSE OF BELONGING TO THE COUNTRY: EXPLORING A NEW MODEL
}

\author{
Aleksandrs Kolesovs \\ University of Latvia, Latvia \\ Ieva Melne \\ University of Latvia, Latvia
}

\begin{abstract}
This study explored new possibilities for measuring the sense of belonging to the country and investigated predictors of the sense of belonging to Latvia. Focusing on students' sense of belonging to the country is explained by two reasons: 1) emigration is the main factor of depopulation in Latvia; 2) students' intention to emigrate is the highest among other social groups. Studies in the field of community psychology present models of the sense of community and explore intentions to stay in a particular place. Within a new model, different levels of social systems (from meso- to macro-system) were included into the analysis of predictors of the sense of belonging to the country. The participants were 205 university students from 18 to 30 (67\% females). On the basis of previous studies, a new measure of the sense of belonging and perceived context was developed. The results confirmed a complex model of the sense of belonging in the context of social systems. Higher perceived opportunities at the level of the country and more positive evaluation of the future of Latvia predicted higher level of the sense of belonging to Latvia directly. In addition, female students perceived higher level of the sense of belonging than male students.
\end{abstract}

Keywords: community, country, ecological systems theory, opportunities, sense of belonging.

\section{Introduction}

The sense of youth's belonging to the country is a challenge for social scientists in Latvia because of two reasons. First, in accordance with the Central Statistical Bureau of Latvia (CSBL, 2016), emigration is the main factor of depopulation in the country. Projected general loss of the population in 2020 is about $10 \%$ (Eurostat, European Commission, 2016). Second, sociological studies (Hazans, 2013; Zepa \& Kḷave, 2011) demonstrate that students are the highest among other social groups in their intention to emigrate.

Studies in the field of community psychology present models of the sense of community (e.g., McMillan \& Chavis, 1986; Tartaglia, 2006) and investigate intentions to stay in a particular living place (e.g., Arcidiacono, Procentese, \& Di Napoli, 2007; Pretty, Chipuer, \& Bramston, 2003). At the same time, there is a

(C) Rēzeknes Tehnoloǵiju akadēmija, 2017

http://dx.doi.org/10.17770/sie2017vol1.2325 
limited number of psychological studies on belonging to the country. In addition, measures of the sense of belonging differ in their content because of specific research objectives. For example, a study on post-traumatic growth (Dekel \& Nuttman-Shwartz, 2009) included terrorist attacks as a challenge for the sense of belonging, while study on adolescent immigrants emphasized aspects of their cultural identity (Tartakovsky, 2009). The aim of this study was to explore new possibilities for measuring the sense of belonging to the country and to investigate predictors of the sense of belonging to Latvia.

\section{Sense of belonging to the country and its predicting}

It should be noted that there is no uniformity in uses of the concept of belonging in psychological studies. Community studies represent the sense of belonging as an element of a broader sense of community involving individual bounds to the community and identification with it (e.g., McMillan \& Chavis, 1986). Some models of the sense of community (Tartaglia, 2006) include attachment to the community instead of the sense of belonging. At the level of a society, attachment to the country is also mentioned in studies on patriotism (Huddy \& Khatib, 2007; Schatz, Staub, \& Lavine, 1999). More critical view (Miller, 2003) emphasizes that attachment represents individual feeling, while belonging relates to social, historical, and territorial connections. Studies on the sense of community revealed also temporal aspect of the sense of belonging, which manifests in planning personal future as more or less associated with the living place (Arcidiacono et al., 2007; Pretty et al., 2003). As a result, in the current study, the sense of belonging was defined as perceived ties with the country or the community, which can be measured as the level of association of personal life with it in the present and in the future.

Theoretical models (Bronfenbrenner, 1979; Pinquart \& Silbereisen, 2004) emphasize significance of multiple levels of social systems - from micro- (dyadic relations) through meso- (for example, family as joined micro-systems) to macrosystem (society) - in understanding social phenomena. Taking ecological systems theory perspective (Bronfenbrenner, 1979), it is possible to expect that predictors of the sense of belonging to the country can be revealed at different levels of social systems. First, perceived support at the level of meso-system should be included into the analysis (Arcidiacono et al., 2007). Second, the level of a community can involve perceived opportunities for need fulfilment and individual views of the future of the community (Arcidiacono et al., 2007; Tartaglia, 2006). In addition, the sense of belonging to the community can be among the predictors of the sense of belonging to the country. Third, perception of the situation at the macro-level (country) seems important element of association of personal life with the country. It was demonstrated in the study on university students' views of the 
future of Latvia and Russia (Kolesovs \& Kashirsky, 2015). Students from Latvia mentioned emigration as a topical problem of the country and discussed it in the context of opportunities for personal development and of belonging to the country in the future. Connections between perceived contextual opportunities and goal setting and life planning are also emphasized in the models of future orientation (Nurmi, 1991) and socialization (Nurmi, 2004). As a result, prediction of the sense of belonging to the country was planned within a path model presented in Figure 1.

\section{$\begin{array}{cc}\text { LEVEL OF } & \text { MACRO-LEVEL } \\ \text { MESO-LEVEL COMMUNITY }\end{array}$}

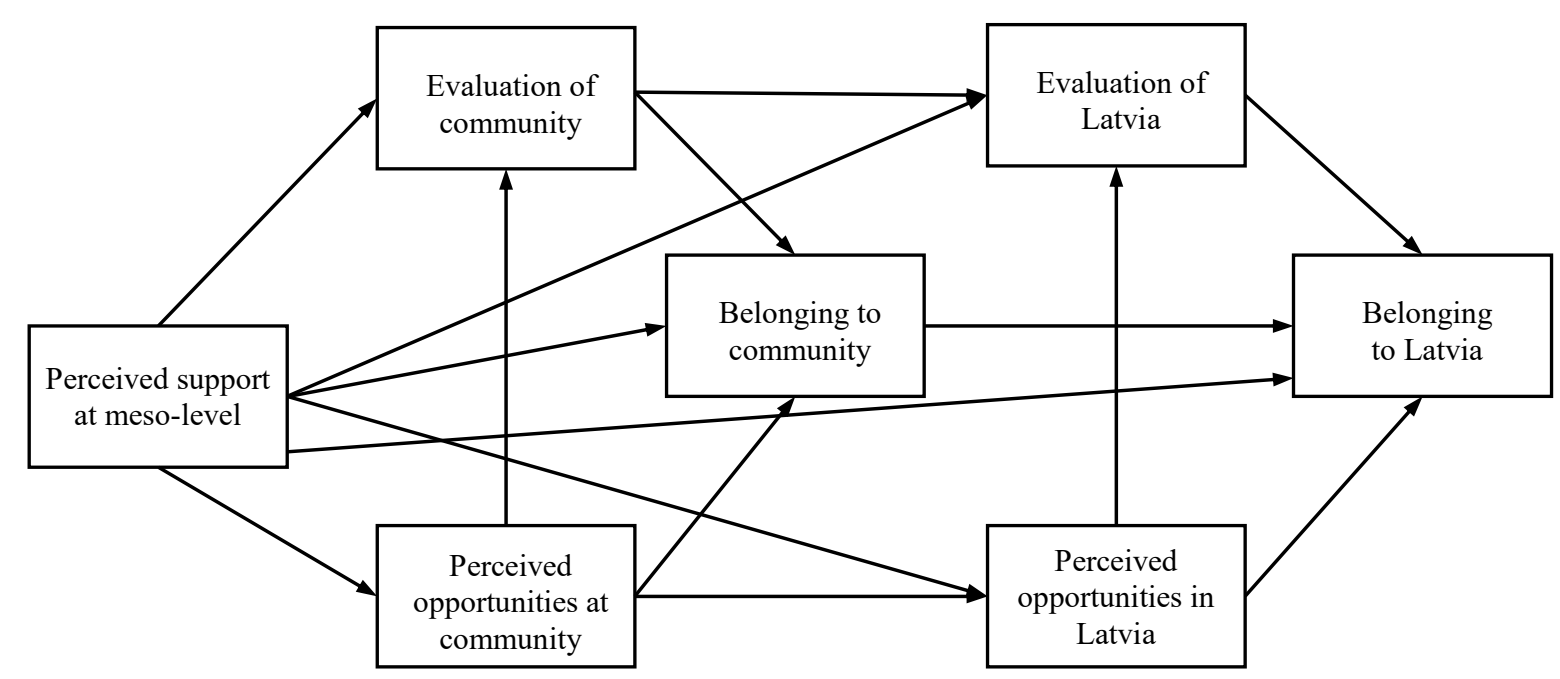

Figure 1 A model of predicting the sense of belonging to the country

As Figure 1 demonstrates, connections between similar constructs at the level of community and of the country were expected (e.g., belonging to the community can predict belonging to the country). Taking into account the results of a study on the sense of community (Arcidiacono et al., 2007), perceived mesosupport was considered as impacting any variable at higher levels. Following the model of future orientation and a sequence of interrelated processes (Nurmi, 1991), perceived contextual opportunities were selected as predictors of evaluation of the community or of the country. In order to explore the model, it was analyzed without latent variables. Reliability of the measurements and model fit were the main focuses of the assessment.

\section{Method}

Participants. The participants were 205 university students from 18 to 30 (mean age $=22.19, S D=2.57,67 \%$ were females). Students were from Riga and 
Daugavpils, and the most of them (67\%) were studying at their living place. One fourth ( $25 \%$ ) of participants have completed some level of higher education, $48 \%$ of participants were employed, $8 \%$ married, $8 \%$ having children, and $61 \%$ of them indicated their income range above the mean income per person in a household in Latvia (CSBL, 2014). Students' mother tongue was Latvian (64 \%), Russian (34\%), or other language or bilingual (2\%). In order to include an ethnolinguistic group into the analysis, it was performed in a sample of 201students indicating Latvian or Russian language as their mother tongue. The number of participants was sufficient for the assessment of a model without latent variables.

Measures. A new questionnaire was based on a combination of measures presenting personal goals in a context (Kolesovs, 2015) and the Future of Country Questionnaire, FCQ (Kolesovs \& Kashirsky, 2014). The Sense of Belonging in Social Context Questionnaire was developed in Latvian (see Appendix). Variables at meso-, community-, and macro-level were assessed on a Likert-type 7-point scale (from 1 = 'minimal' to 7 = 'maximal').

Macro-level. A new measure of belonging to the country included three items addressing the level of association of personal life with Latvia in the present and in the near and distal future. The question was common for three temporal frames: "To what extent do you associate your life with Latvia?"

Evaluation of the present and of the near and distal future of Latvia was assessed in accordance with the FCQ. In addition, by analogy with a study on perceived social context (Kolesovs, 2015), perceived opportunities for fulfilment of near and distal personal goals in Latvia were assessed by asking "Does Latvia provide opportunities for fulfilment of your goals?"

Community level. Perceived belonging to the community in the present and in the near and distal future was assessed by analogy with belonging to the country asking: "To what extent do you associate your life with your living place?" Perceived opportunities for fulfilment of near and distal personal goals at the living place were assessed by asking "Does your living place provide opportunities for fulfilment of your goals?" Cronbach's alpha for this measure was .74 (Kolesovs, 2015). Evaluation of the present and of the future of the living place was similar to their measures at the macro-level.

Meso-level. Perceived support at the meso-level was evaluated as support for individual goal attainment provided by parents, siblings, relatives, and friends by asking "To what extent your goals are supported by people listed below?" $(0=$ 'not topical'; 1 = 'minimal support'; 6 = 'maximal support'). Cronbach's alpha coefficient for the sub-scale was .70 (Kolesovs, 2015).

It should be noted that some measures were not included into the analysis because of complexity of the model, relatively small number of research participants, and failures in building a subscale (e.g., one-item measures). As a 
result, attachment to the living place, perceived power and stability of Latvia, and perceived personal control over the context were excluded from the analysis.

Procedure. Participation in the study was voluntary and anonymous. The questionnaire was answered without time limit in groups or individually. IBM SPSS for Windows 22.0 was applied for the assessment of reliability coefficients and descriptive statistics. Statistical package 'lavaan' (0.5-22) for $R$ (Rosseel, 2012) was used for the assessment of the path model.

\section{Results}

At the first step, reliability of measures was assessed (Table 1). Cronbach's alpha coefficients confirmed sufficient reliability of the subscales.

Table 1 Reliability and descriptive statistics for measures $(\boldsymbol{N}=\mathbf{2 0 5})$

\begin{tabular}{|c|c|c|c|c|}
\hline \multicolumn{1}{|c|}{ Variables } & $\begin{array}{c}\text { Number } \\
\text { of items }\end{array}$ & $\boldsymbol{\alpha}$ & $\boldsymbol{M}$ & $\boldsymbol{S D}$ \\
\hline Meso-level & & & & \\
\hline Perceived support & 4 & .71 & 3.86 & 1.25 \\
\hline Level of community & & & & \\
\hline Opportunities for personal goals & 2 & .80 & 4.82 & 1.57 \\
\hline Evaluation of the living place & 3 & .86 & 5.07 & 1.19 \\
\hline Belonging to the living place & 3 & .80 & 4.78 & 1.51 \\
\hline Macro-level (Latvia) & & & & \\
\hline Opportunities for personal goals & 2 & .78 & 5.35 & 1.31 \\
\hline Evaluation of Latvia & 3 & .88 & 4.37 & 1.32 \\
\hline Belonging to Latvia & 3 & .78 & 5.65 & 1.24 \\
\hline
\end{tabular}

Second, a correlation analysis was performed in order to assess relationships between SES and the sense of belonging to Latvia. Pearson correlation coefficients determine positive statistically significant correlation of the sense of belonging with female gender, $r(203)=.16, p=.023$; having children, $r(203)=$ $.14, p=.039$; studying in Riga, $r(203)=.16, p=.023$, and the Latvian ethnolinguistic group, $r(199)=.19, p=.006$.

Third, the model of predicting of the sense of belonging was tested. The initial model was extended by demographic variables correlated with the sense of belonging to Latvia. These demographic indicators were added as exogenous variables. Satorra-Bentler correction was applied in order to assess model fit through maximum likelihood method. The model fit was acceptable: $\chi^{2}(4)=$ $10.38, p=.035, \mathrm{CFI}=0.98, \mathrm{TLI}=.75$, RMSEA $=.09(90 \% \mathrm{CI}$ from .03 to .15 , $p=.12), \mathrm{SRMR}=.023$. However, relatively low TLI and broad confidence 
interval for RMSEA indicated a need for the further model development. Figure 2 represents significant regression coefficients and covariates between predictors.

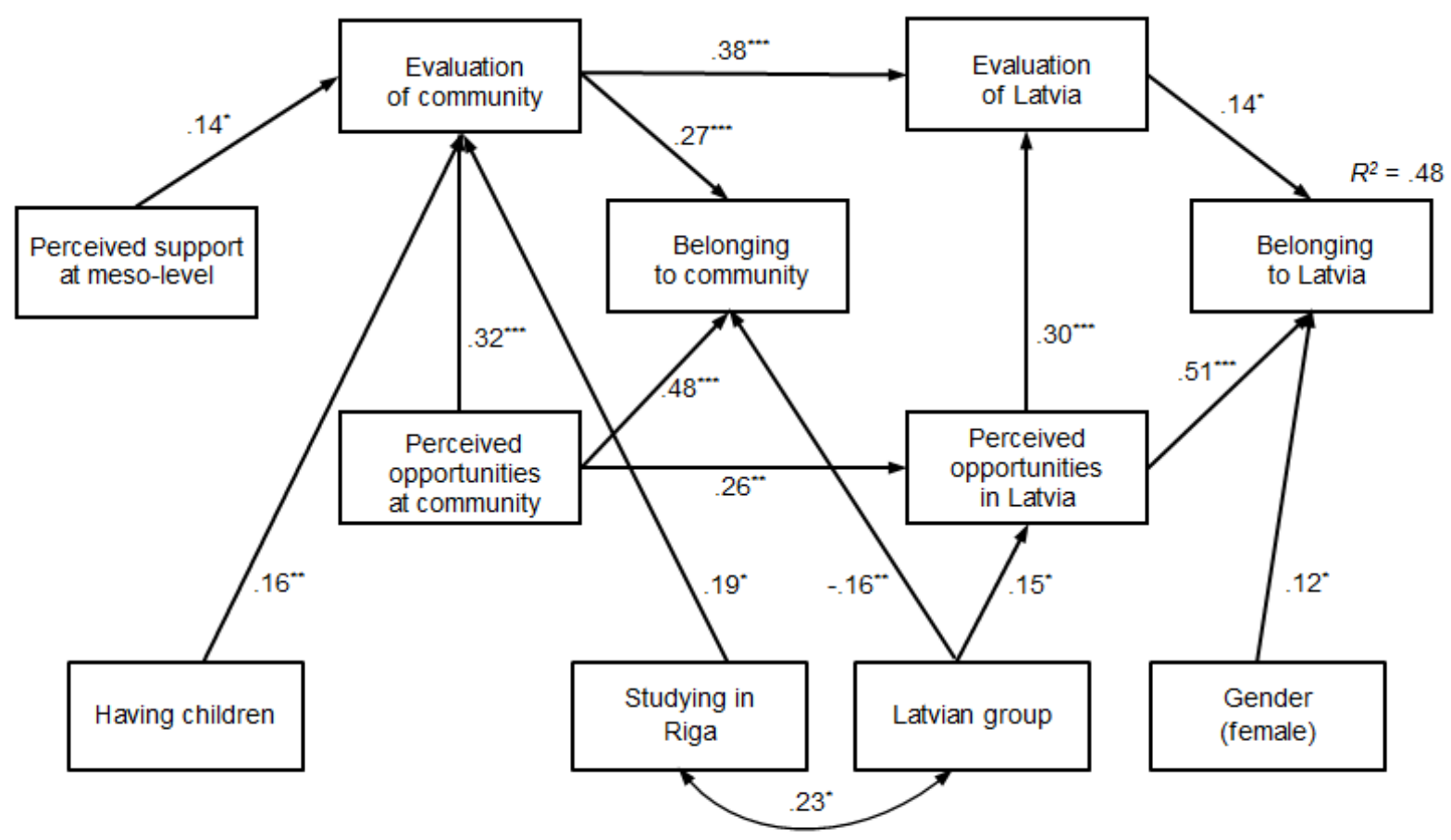

Notes: Standardized coefficients are presented. Errors and nonsignificant paths are omitted ${ }^{*} p<.05 .{ }^{* \star} p<.01 .{ }^{* \star *} p<.001$.

Figure 2 Path model for the sense of belonging to Latvia on demographic, meso-, community-, and macro-level variables $(n=201)$

Perceived opportunities for fulfilment of personal goals in Latvia, evaluation of Latvia, and female gender predicted the sense of belonging to Latvia directly. Belonging to the community was not among significant predictors. At the same time, higher evaluation of the community predicted higher evaluation of Latvia, and higher opportunities for personal goals at the level of community predicted higher opportunities for personal goals in Latvia. Perceived support within a meso-system was not associated with the sense of belonging to Latvia. This kind of support was a predictor for more positive evaluation of the situation in the community only. At the level of community and at the level of Latvia, higher perceived opportunities for fulfillment of personal goals predicted higher evaluation of the situation and higher sense of belonging.

Among demographic variables, having children predicted higher evaluation of the community, studying in Riga predicted higher level of belonging to the living place, and reporting Latvian as the mother tongue predicted higher perceived opportunities at the level of the country and lower level of the sense of 
belonging to the community. For the sense of belonging to Latvia, an effect of ethnolinguistic group was not significant.

\section{Discussion}

The results demonstrated that, within the model suggested for the study, direct predictors of the sense of belonging to Latvia are revealed at the level of the country. The main predictor is perceived opportunities provided by Latvia for fulfilment of personal goals. This finding confirms significance of contextual opportunities in goal setting, planning, and individual socialization (Nurmi, 1991, 2004). By analogy with the study on the sense of community (Arcidiacono et al., 2007), it is possible to hypothesize that young people's further decisions on the mobility and emigration are construed on the basis of perceived opportunities provided by Latvia. Links between satisfaction with opportunities, sense of belonging to the country, emigration intentions, and following decisions and action should be tested in the further studies.

Positive view of the future of Latvia as a predictor of a higher sense of belonging to it confirms lower distancing from the social context in the case of more optimistic view of its future (Arcidiacono et al., 2007). Negative view of the future of the country can challenge individual affective ties with it. In this case, lower sense of belonging reflects some kind of coping with negative expectations regarding the country, as it was concluded in a study on the future of a country (Kolesovs \& Kashirsky, 2014).

Female university students demonstrated higher sense of belonging to Latvia. Closer ties with a community in females were revealed in a structural modelling of the sense of community performed by Tartaglia (2006) and in a comparison made by Pretty et al. (2003). On the one hand, the results confirm that females can be more oriented on maintaining closer ties with the social context. On the other hand, the current study does not confirm that gender predict higher sense of belonging to the community. Therefore, more detailed analysis of the effect of gender is in question for the further research.

The sense of belonging to the community does not predict the sense of belonging to Latvia. It can be concluded that a tie between these senses is not close. Further exploration of the relationship between senses of belonging should involve ethnicity of participants because of three findings. First, there is an association of lower sense of belonging to the community with Latvian group. Second, the ethnolinguistic group was not a predictor of the sense of belonging to Latvia. Third, Latvian group perceived higher opportunities for personal goals at the level of Latvia (the main predictor of the sense of belonging). Therefore, different patterns of prediction of the sense of belonging to Latvia are possible within Russian (minority) and Latvian (majority) group. 
A common tendency of prediction of the sense of belonging by perceived opportunities for personal goals and evaluation of the situation is in accordance with findings of Arcidiacono et al. (2007). A limited role of perceived mesosupport indicates possible cultural differences between Latvian and Italian views on family and close relationships.

In comparison with sociological studies, the current study is limited by representativeness of the sample. Another limitation is associated with a model suggested for the analysis. The further study can focuses on latent variables and indirect effects in prediction of the sense of belonging to the country. In addition, an exploration of intentions to emigrate can be focused on assessment of perceived opportunities for reaching personal goals outside Latvia.

In summary, developed model of the sense of belonging to the country reveals its associations with variables at the macro-level. Fostering active exploration of opportunities for achieving personal goals is the main way of facilitating students' belonging to Latvia.

\section{References}

Arcidiacono, C., Procentese, F., \& Di Napoli, I. (2007). Youth, community belonging, planning and power. Journal of Community \& Applied Social Psychology, 17, 280-295.

Bronfenbrenner, U. (1979). The ecology of human development: Experiments by nature and design. Cambridge, MA: Harvard University Press.

Central Statistical Bureau of Latvia (2014). Income and living conditions in Latvia, 2013. Collection of statistical data (14). Riga: CSB of Latvia. Retrieved from http://www.csb.gov.lv/sites/default/files/nr_14_ienakumi_un_dzives_apstakli_latvija_2 013_14_00_lv_en.pdf

Central Statistical Bureau of Latvia (2016). Demography 2016. Collection of statistical data. Riga: CSB of Latvia.

Dekel, R., \& Nuttman-Shwartz, O. (2009). Posttraumatic stress and growth: The contribution of cognitive appraisal and sense of belonging to the country. Health and Social Work, 34, 87-96.

Eurostat, European Commission (2016). Population (Demography, Migration and Projections) [Interactive map]. Retrieved from http://ec.europa.eu/eurostat/web/populationdemography-migration-projections/statistics-illustrated

Hazans, M. (2013). Emigration from Latvia: Recent trends and economic impact. In OECD, Coping with Emigration in Baltic and East European Countries (pp. 65-110). Paris: OECD Publishing. http://dx.doi.org/10.1787/9789264204928-7-en

Huddy, L., \& Khatib, N. (2007). American patriotism, national identity, and political involvement. American Journal of Political Science, 51, 63-77.

Kolesovs, A. (2015). Prediction of distant educational goals by goals in other domains and perceived contextual opportunities. In Lubkina, V., \& Usca, S. (Eds.), Society, Integration, Education: Vol. 4. Proceedings of the International Scientific Conference (pp. 40-47). Rēzekne: Rēzeknes Augstskola.

Kolesovs, A., \& Kashirsky, D. V. (2014). Anticipated future of Latvia and Russia during a global economic crisis: A mixed methods perspective. Psihologija, 47, 153-167. 
McMillan, D. W., \& Chavis, D. M. (1986). Sense of community: A definition and theory. Journal of Community Psychology, 14, 6-23.

Miller, L. (2003). Belonging to country - A philosophical anthropology. Journal of Australian Studies, 27 (76), 215-223.

Nurmi, J.-E. (1991). How do adolescents see their future? A review of the development of future orientation and planning. Developmental Review, 11, 1-59.

Nurmi, J.-E. (2004). Socialization and self-development: Channeling, selection, adjustment, and reflection. In R. Lerner, \& L. Steinberg (Eds.), Handbook of adolescent psychology (pp. 85-124). New York, NY: Wiley.

Pinquart, M., \& Silbereisen, R. K. (2004). Human development in times of social change: Theoretical considerations and research needs. International Journal of Behavioral Development, 28, 289-298.

Pretty, G. H., Chipuer, H. M., \& Bramston, P. (2003). Sense of place amongst adolescents and adults in two rural Australian towns: The discriminating features of place attachment, sense of community and place dependence in relation to place identity. Journal of Environmental Psychology, 23, 273-287.

Rosseel, Y. (2012). lavaan: An R Package for Structural Equation Modeling. Journal of Statistical Software, 48 (2), 1-36. http://www.jstatsoft.org/v48/i02/

Schatz, R. T., Staub, E., \& Lavine, H. (1999). On the varieties of national attachment: Blind versus constructive patriotism. Political Psychology, 20, 151-174.

Tartaglia, S. (2006). A preliminary study for a new model of sense of community. Journal of Community Psychology, 34, 25-36.

Tartakovsky, E. (2008). Cultural identities of adolescent immigrants: A three-year longitudinal study including the pre-migration period. Journal of Youth and Adolescence, 38, 654671.

Zepa, B., \& Kḷave, E. (2011). Latvia. Human Development Report 2010/2011. National Identity, Mobility and Capability. Riga: Advanced Social and Political Research Institute of the University of Latvia.

\section{The Sense of Belonging in Social Context Questionnaire (SBSCQ) Aptauja "Piederības izjūta sociālajā kontekstā"}

Instrukcija: Aptaujā ir iekḷauti jautājumi par Jūsu priekšstatiem par tagadni un nākotni.

Runa ir par Jūsu viedokli, tāpēc nevar būt "pareizās" vai "nepareizās" atbildes. Atbildot uz jautājumiem, lūdzu, apvelciet piemērotu atbildes variantu.

JŪSU DZĪVESVIETA (pilsēta, ciemats...)

1. Cik lielā mērā Jūs saistāt savu dzīvi ar vietu, kurā Jūs dzīvojat?

\begin{tabular}{lccccccc}
\hline & Minimāli & \multicolumn{3}{c}{} & \multicolumn{2}{c}{ Maksimāli } \\
\hline Tagad & 1 & 2 & 3 & 4 & 5 & 6 & 7 \\
Tuvākajā nākotnē & 1 & 2 & 3 & 4 & 5 & 6 & 7 \\
Tālākajā nākotnē & 1 & 2 & 3 & 4 & 5 & 6 & 7 \\
\hline
\end{tabular}

2. Vai Jūsu dzīvesvieta sniedz iespējas Jūsu mērḳu sasniegšanai?

\begin{tabular}{lccccccc}
\hline & Nemaz & & & & & Maksimāli \\
\hline Tuvākie mērḳi & 1 & 2 & 3 & 4 & 5 & 6 & 7 \\
Attālinātie mērkii & 1 & 2 & 3 & 4 & 5 & 6 & 7 \\
\hline
\end{tabular}


3. Lūdzu, novērtējiet situāciju vietā, kurā Jūs dzīvojat.

\begin{tabular}{lccccccc}
\hline & $\begin{array}{c}\text { Loti } \\
\text { negatīva }\end{array}$ & & & & & Loti \\
Tagad & -3 & -2 & -1 & 0 & +1 & +2 & +3 \\
Tuzāitīva
\end{tabular}

4. Cik lielā mērā Jūs saistāt savu dz̄ivi ar Latviju?

\begin{tabular}{|c|c|c|c|c|c|c|c|}
\hline \multicolumn{4}{|c|}{ Minimāli } & & & \multicolumn{2}{|r|}{ Maksimāli } \\
\hline Tagad & 1 & 2 & 3 & 4 & 5 & 6 & 7 \\
\hline Tuvākajā nākotnē & 1 & 2 & 3 & 4 & 5 & 6 & 7 \\
\hline Tālākajā nākotnē & 1 & 2 & 3 & 4 & 5 & 6 & 7 \\
\hline \multicolumn{8}{|c|}{ 5. Vai Latvija sniedz iespējas Jūsu mērķu sasniegšanai? } \\
\hline \multicolumn{5}{|c|}{ Nemaz } & & \multicolumn{2}{|r|}{ Maksimāli } \\
\hline Tuvākie mērķi & 1 & & 3 & 4 & 5 & 6 & 7 \\
\hline Attālinātie mērķi & 1 & & 3 & 4 & 5 & 6 & 7 \\
\hline \multicolumn{8}{|c|}{ 6. Lūdzu, novērtējiet situāciju Latvijāa.* } \\
\hline & $\begin{array}{c}\text { Lyoti } \\
\text { negatīva }\end{array}$ & & & & & & $\begin{array}{c}\text { Loti } \\
\text { pozitīva }\end{array}$ \\
\hline Tagad & -3 & -2 & -1 & 0 & +1 & +2 & +3 \\
\hline Tuvākajā nākotnē & -3 & -2 & -1 & 0 & +1 & +2 & +3 \\
\hline Tālākajā nākotnē & -3 & -2 & -1 & 0 & +1 & +2 & +3 \\
\hline
\end{tabular}

* An item from the FCQ (Kolesovs \& Kashirsky, 2015, 167). 